\title{
Higher Education and Creation of Jobs in Bangladesh
}

\author{
M. M. Shahidul Hassan ${ }^{1 *}$ and Omiya Hassan ${ }^{2}$ \\ ${ }^{1}$ Vice Chancellor, East West University, Dhaka, Bangladesh \\ ${ }^{2}$ Graduate Student, Department of Electrical Engineering and Computer Science, University \\ of Missouri, Columbia, USA, omiya.hassan21@gmail.com
}

ARTICLE INFO

\begin{tabular}{l}
\hline Keywords: \\
Higher Education \\
Teaching and Learning \\
Assessment Methods \\
Knowledge-Based \\
Society \\
Bangladesh
\end{tabular}

\begin{abstract}
This study uses the data from the Bangladesh Bureau of Statistics, Bangladesh Economic Update, and Bangladesh Export Promotion Bureau to investigate the role of higher education in creating new jobs in Bangladesh. Every year about three million youths are entering job markets. But industry and service sectors do not develop much to provide jobs for such large youth job seekers. This challenge can be faced if universities produce graduates with high level skill and innovative quality. With such graduates Bangladesh can create knowledge-based society and more opportunities will be created for them to get jobs in global markets, and graduates can be successful as entrepreneurs and self-employed workforce. Such dispositions demand changes in curricular, teaching and assessment methods to function young generation as active learners and creators. A simple economic model is used to study the relationship between per capita Gross Domestic Product (GDP) and the three economic sectors, namely agriculture, industry and services sectors for Bangladesh. Using available data both correlation analysis and multiple regression analysis are used to examine the relationship between the dependent variable and the independent variables in the study. The results of this study have implications for economic development policy in Bangladesh.
\end{abstract}

\section{Introduction}

Education is now considered a crucial input into the development process. But it is not clear which level of education is appropriate for development in the context of low income and middle income countries and whether all development outcomes are equally affected by all levels of education. In many countries in Asia the focus was on primary and secondary education, since more people can be reached with the same investment. However, since last few decades there has been an increasing understanding that higher education plays a key role in economic development (Kruss, 2015), (Brown \& Lauder, 1996), [UNESCO, 1991) the countries even in Asia are focusing on higher education (Shin, 2018), (Oliver, 2004). The widely adopted human capital view is that higher education increases skill and knowledge and results in higher income.

Question now arises about type of higher education universities will provide to students with individual prosperity and with which they can contribute more to the economic development of a country. Economists and educationists have agreed that a country with large youth population can spawn as an economic development country by creating knowledge-based society (Kefela, 2016), (Lopes, 2017), (McCowan \& Schendel, 2015). Increased importance

* Corresponding Author E-Mail Address: vc@ewubd.edu 
of knowledge provides great potential for countries to strengthen their economic and social development by providing more efficient ways of producing goods and services and delivering those more effectively and at lower costs to a greater number of people.

The Bangladesh government is hopeful in meeting the economic target of reaching Middle Income Country (MIC) status in 2023 by ensuring an annual 8\% GDP growth and will become a developed country by 2041. This paper identifies the challenges that Bangladesh faces in developing it as a developed country by 2041 and providing jobs for the 30 million young people set to join the labour force over the next decade. The analysis shows that if Bangladesh forges a path towards creating knowledge-based economy and society then Bangladesh will become a developed country.

\section{Economic Sectors and Bangladesh's Employment Conundrum}

The population with age 15-24 in Bangladesh is increasing and the predicted population in 2021 is found to be $31,845,969$ (Hassan, 2016). About three million youths are joining the job market every year. Bangladesh now faces a tremendous challenge in creating opportunity for the large youth population. The country ought to promote its service sector, agricultural sector, manufacturing and assembling industry sector and information technologies sector. Otherwise, Bangladesh will not attain the status of developed country by 2041 . Only 23 years are left and the country needs to make per capita income more than US\$12,000, which is an eightfold increase from the current level of around US\$1,600. Sector share of GDP as percentage is shown in Figure1 (a), while Figure1 (b) shows growth rate of different economic sectors.

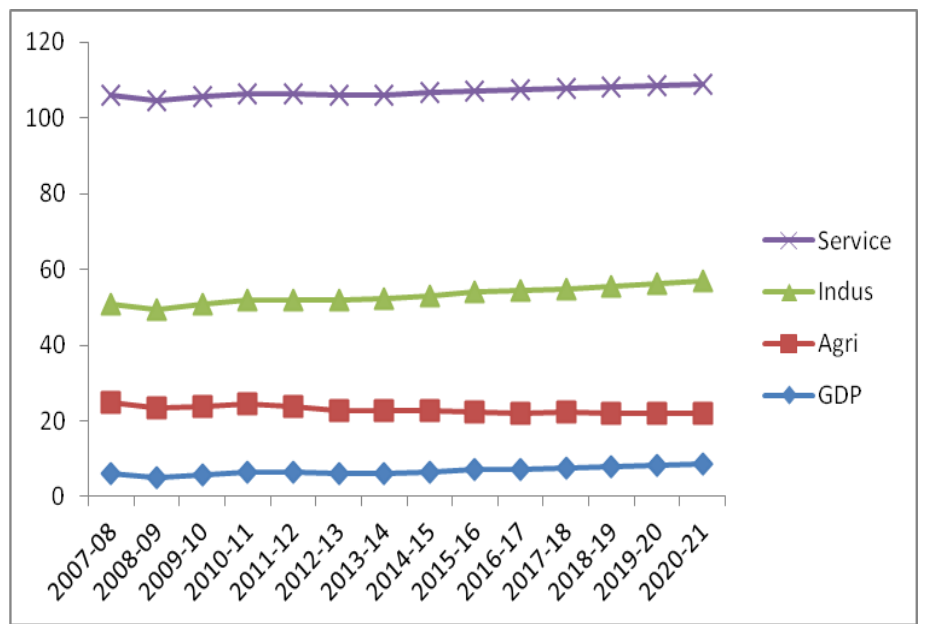

Figure 1(a). Sectoral Shares of GDP (\%) at constant price base year 2005-06

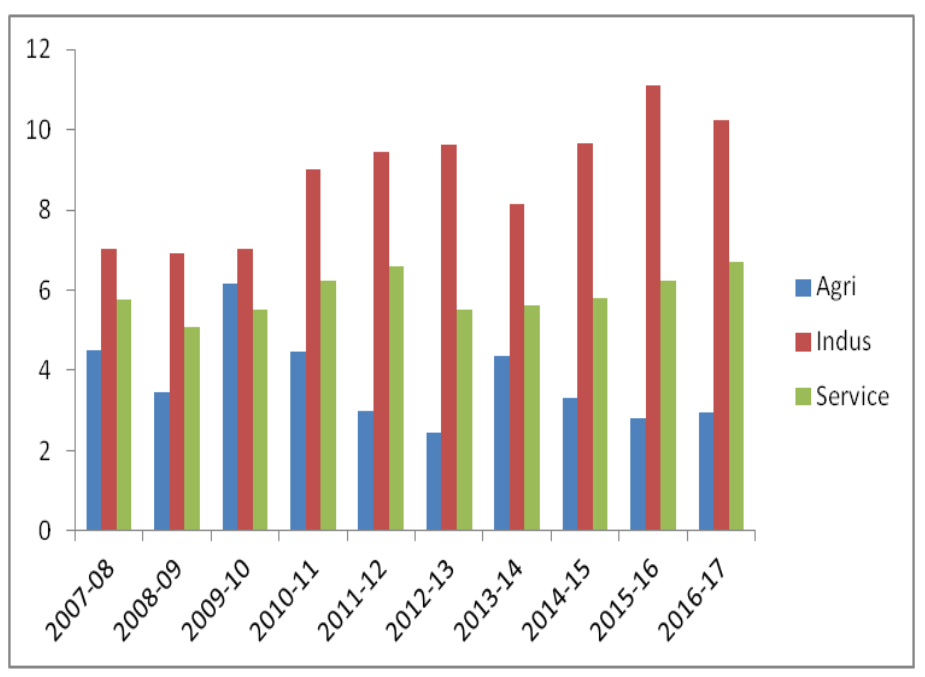


Figure 1(b). Sectoral Growth Rate of GDP (\%) at constant price base year 2005-06

Contribution of Agriculture, Industry and Service Sectors to Bangladesh GDP in 1972 (soon after the independence) was 59.60\%, 6.06\% and 34.32\% respectively (Abdin, (2016), (BBS, 2016),(BEPB, 2017). In the year 2016-2017 contribution of agriculture reduced into 14.74 per cent, industry increased into 32.42 per cent and Service increased into 52.85 per cent to the Bangladesh GDP. From the above statistics reveals that Bangladesh economy is transforming from an agriculture dependent economy into an industry dependent economy. Though industry has small share of GDP compared to that of service sector, its growth rate is higher and has expectedly exceeded GDP growth [Figure 1 (b)]. On the other hand, till now agriculture is the single largest sector for employment generation, agriculture employed 24.7 millions which is 47.5 per cent of total labour force (15+) to contribute $14.74 \%$ (Figure 2).

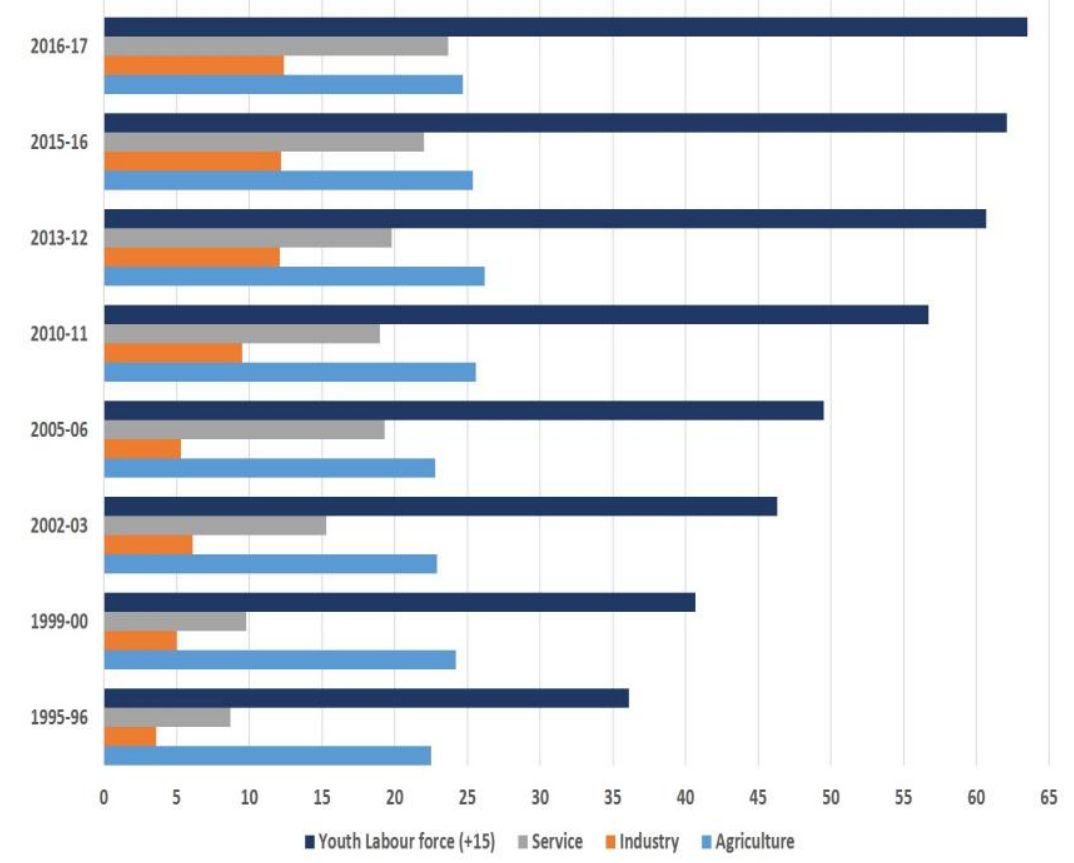

Figure 2. Share in employment in different sectors

Though the employment is largest in agriculture sector, its contribution to GDP is decreasing. That means productivity of agriculture sector is lower than that of the other sectors or manpower employed in agriculture sector are underutilized. There are not much Job opportunities created for youths having university degrees (Figure 3). 


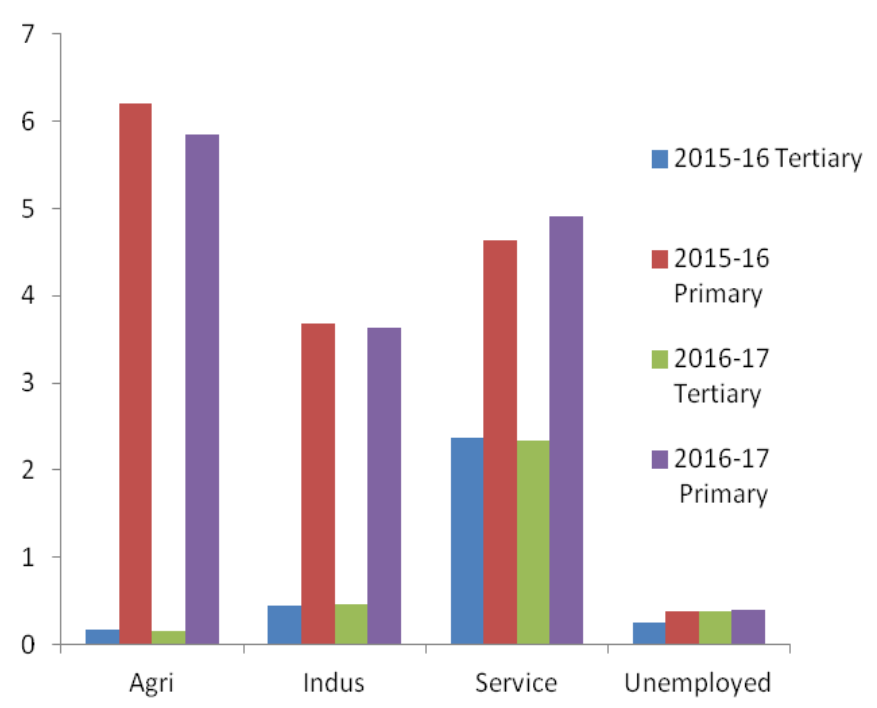

Figure 3. Employment by different education levels.

Per capita income in 2016-17 was US\$1610 and it is predicted (BEU,2016) that per capita income in 2020-21 will be US\$2174. GNI per capita is plotted as a function of year which is shown in Figure 4 with an increse of GNI of $11.225 \%$ (Figure 4). To acchive the target of capita income in 2020-21 will be US\$ 2174. To acchive the target of GNI of US\$12,000, an anlysishas been carried out using available data (BBS, 2016). Elasticity results show that average increase of GNI will be approximately $14.52 \%$ from 2020-21 which will not be unreachable, though a quite difficult given its past growth experiences and prevailing of infrastructure and political instability. In order to attain the status of developed country by 2041, government must immediately adopt a development plan with an aim to increase national income, rural development, self-sufficiency in food, and increase industrial production. It is widely accepted that manufacturing output results in the increase of employment which in turn involves transfer of labour from lower productivity land-based activities. Manufacturing is more important for economic growth while services sector is important for labour absorption. Technology based manufacturing industries create jobs for university graduates. Government must create opportunities for the youth in the Small Manufacuturing Industries (SME), start up industries, entrepreneurship and information technology sector. In the present analysis a high rate of grow of these sectors is predicted to achieve the set GNI target.

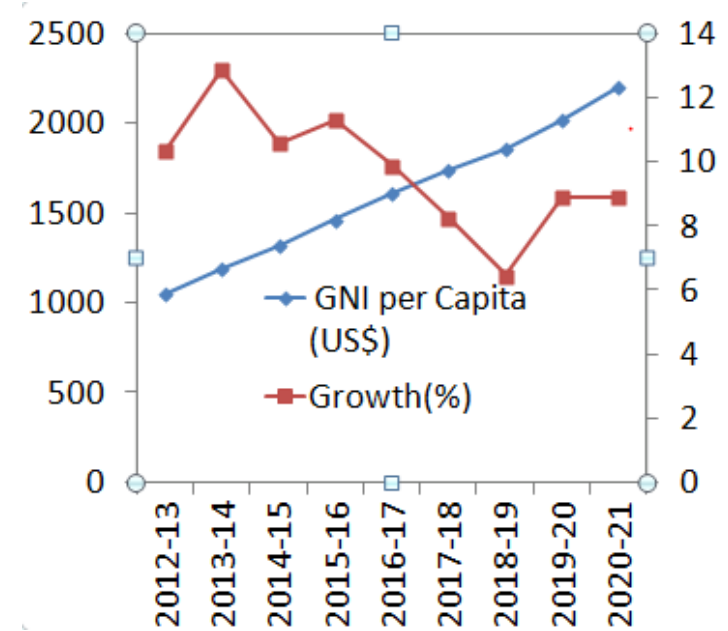

Figure 4. Employment by different education levels. 


\subsection{Methodology used}

Correlation analysis and multiple regression analysis are used to examine the relationship between the dependent variable and the independent variables in the study. The following model is used to represent the relationship between per capita real Gross Domestic Product (GDP) and the three economic sectors, namely agriculture, industry and services sectors for Bangladesh. The equation for the multiple regression analysis is:

$$
\operatorname{GDP}=\beta_{0}+\beta_{1} \operatorname{Agr}+\beta_{2} \text { Ind }+\beta_{3} \operatorname{Serv}+\mu
$$

Where,

Agr $=$ Share of value added in agriculture sector to GDP per capita, Ind $=$ Share of value added in industry sector to GDP per capita, Serv = Share of value added in services sector to GDP per capita. $\beta_{0}$ is the intercept, $\beta_{1}, \beta_{2}$, and $\beta_{3}$ are coefficients. The factor $\mu$ is the Error Term. The stationary properties of the variables have been ensured. This study uses Augmented Dickey Fuller (ADF) test (Dickey \& Fuller, 1981), to perform the unit root tests. The ADF test includes extra lagged terms of the dependent and independent variables, which are GDP per capita, agriculture sector, industry sector and services sector in order to eliminate autocorrelation.

This study uses a regression model that includes an intercept and a time trend:

$$
\Delta Y_{\mathrm{t}}=\beta_{0+} \beta_{1} t+\beta_{2} Y_{\mathrm{t}-1}+\sum_{\mathrm{i}=}^{k} \alpha_{\mathrm{i}} \Delta Y_{\mathrm{t}-1}+\mu_{\mathrm{t}}
$$

Where, $\alpha_{i}$ is a coefficients.

The ADF regression tests for the existence of unit roots of $Y_{t}$, namely all model variables at time $t$. The variable $\mathrm{Y}_{\mathrm{t}-1}$ represents the first differences with $k$ lags while $\mu_{\mathrm{t}}$ is a variable that adjusts the errors of autocorrelation. The Augmented Dickey-Fuller (ADF) and PhillipsPerron (PP) unit root tests use intercept and trend and test for variables' stationary at levels and first differences. In the estimation process, the study has examined the stationary properties of the data series. After examining the stationary of these series, Johansen's and Juselius method (Johansen \& Juselius, 1990), is used to test for co-integration between the series of Agriculture, Industry, Service sector and GDP growth. Co-integration means that despite being individually non-stationary, a linear combination of two or more time series data can be stationary (Gujarati, 2011). Causality test among the variables are based on Error Correction Model with first difference.

\section{Higher Education Scenario in Bangladesh}

Enhancing country's productivity and competitiveness is now felt more important than ever. Educated youths with creative and innovative skills are potential workforce behind the productivity explosion. Higher education is, therefore, now about developing flexible, creative and well rounded individuals. Subsequently, a university's challenge is now to produce graduates with the knowledge and right skills to drive growth and productivity. Universities must then come out from outmoded paradigms.

Starting with 6 public universities Bangladesh has now a total of 43 public universities including national university and Bangladesh Open University, 103 private universities and 3 international universities(UGC, 2016) since its inception as a sovereign country. Out of total 3,157, 598 students, 264, 084 students in public universities, 2,300,053 students in national university, 256,304 students in Bangladesh open university and 337, 157 students in private universities enrolled in 2016. Despite increasing number of universities, it cannot accommodate the huge number of students who pass out HSC examination and rush for admission every year. Employment of university graduates is not satisfactory (Figure 3). Many Teachers in Universities in Bangladesh believe that role of a university is only to create knowledge and transmit it to students. But in this century universities play two important 
responsibilities, developing high level skills and innovative quality. Now, organizations and industries prefer self-directed workers who can adapt and learn quickly. They also need workers who can think critically, communicate and innovate as both industries and markets change and employers are exploring new possibilities. Therefore, it is important for students to learn a core set of knowledge and also to develop skills such as adaptive thinking, communication skills, collaboration skills, critical thinking and problem solving skills, personal management, inquiry skills, technology skills, creativity and innovation, soft skills, empathy and perspective. It is the responsibility of a higher education institution to help its students to develop these 10 skills. Institutions need to engage them in higher-order thinking skills in order for them to develop the skills that will be critical to their future success. Bloom's Taxonomy (Bloom \& Krathwoh, 1964) provides a great illustration of different levels of thinking. Teachers need to stop students depending on the lower level skills, such as memorization and recall, and help students develop higher-order thinking skills such as applying, analyzing, evaluating, and creating. Teacher can create more interest among the students with the use of multimedia, interactive whiteboards, animations and videos. But teachers ought to focus on whether its deployment has the desired effect on student learning (Gibbs, 1992) At present teachers in many universities in USA, Europe and also developed countries in Asia and Africa use a widely accepted model known as student-centred teaching and learning. This model implies a view of teaching that is not just about facts, concepts, and principles to be covered and understood, but which also requires to be clear about: (i) what it is the students are to learn and what are their intended learning outcomes, (ii) what it means for students to understand content in the way that is to do after teachers have taught a topic. It is really not good enough for teachers to talk about it or teach with an impressive array of visual aids: the point, how well the students have learned. Here the teaching and learning activities are specifically attuned to helping students achieve those levels of understanding. Curriculum should not only focus on the tools necessary to develop reasoned and logical construction of new knowledge in various fields of study, but also should aggressively cultivate a culture that nurtures creativity in all our learners (Gibbs, (1992). Students' performance in a course is assessed mainly by examinations, and students depend on memorization of information and procedure in answering questions. Traditional methods of assessment encourage students to take surface approach to learning. Appropriate assessment can encourage students to adopt a deep approach to learning. Students' learning can now be measured by direct and indirect methods. Direct measures provide observable evidence of the students' level of learning. On the course-level this may include homework, quizzes, prelims and exams, reports and term papers, research projects, case study analysis, rubrics for oral and other performances. Indirect measures include course evaluations, student surveys, exit interviews, course enrolment information, focus groups, alumni surveys, graduate school placement rates. If universities can produce graduates who are qualified in competitive global markets, more graduates will get jobs abroad and will increase the number of migrates than that at present.

Higher Education system in Bangladesh relies mainly on traditional methods, it encourages memorization and learning is mainly class room teaching. Students are passive recipients of this methodology. Teaching is deeply teacher-centered. It should be student-centered. This method aims to encourage students to have self-education and one that grows with experience. So the more students are encouraged to learn through hands-on-activities along with theoretical knowledge, the better it is for them because then, retention rate soars up and students know when they can apply that knowledge in the practical life. An idealized conceptual architecture designed for student-centered learning illustrating the processes and systems will help universities in Bangladesh to develop student-centered learning:

(i) Student Profile, (ii) Learning Management, (iii) Online Learning Environment, (iv) 
Assessment Management, (v)Learning Materials Management, (vi) Curriculum Management, (vi) Social Learning and Collaboration, (vii) Evidence of Learning, (viii) Intervention and Support, (ix) Performance Management, (x) Reporting and Analytics, and (xi) Learning Resources Management. This instructional cycle for student-centered learning serves as the foundation for understanding the information systems needed to support these processes.

Department of a university in Bangladesh does not involve students and stakeholders in preparing curriculum of its program. During the initial step of the process of developing a curriculum, extensive feedback should be sought from a range of stakeholders to review the strengths and weaknesses of the current program, seek suggestions for future changes and create new ideas and develop a greater sense of ownership among the stakeholders.

Education system in Bangladesh (Figure 5), particularly vocational education system needs to be reviewed and modified. At present vocational students after studying 14 years can come to university for getting four years bachelor degree. But the society and economy in Bangladesh rely on the vocational system to be highly effective and responsive. In the proposed model presented in Figure 6, after completing five years in school to receive general education the students can choose a path to vocational education and enter university after completing four years at technical institute. In the proposed technical stream students will spend more years in studying technical education.

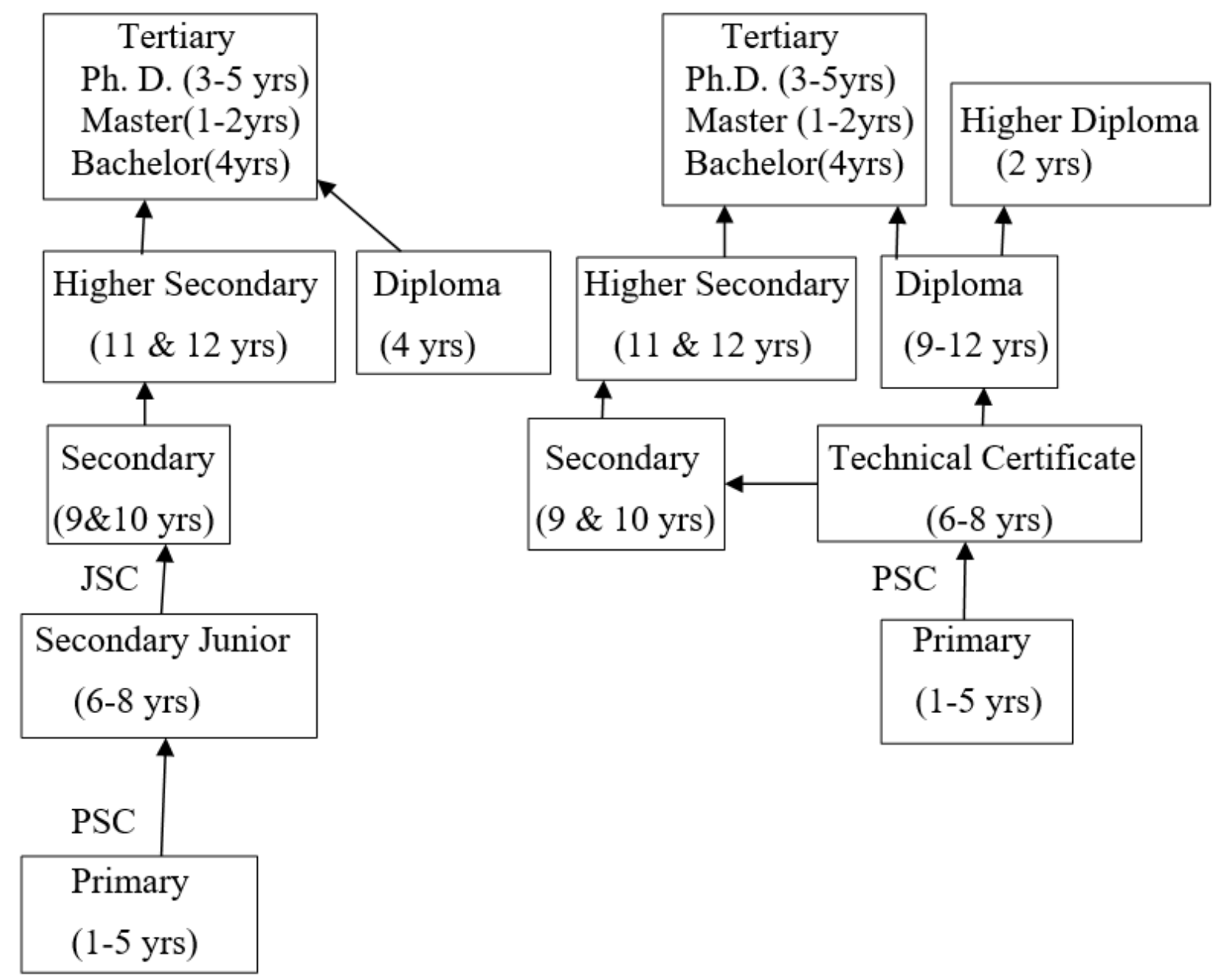

Figure 5. Present Education system in Bangladesh Figure 6. Proposed technical stream JSC is the junior school certificate and PSC is the primary school certificate. 


\section{Conclusion}

Bangladesh needs to invest right now in the human capital of its young people if it wants to reap the benefits of a large demographic dividend. Country needs to put knowledge and innovation policies, as well as higher education, at the core of its development strategies and build indigenous knowledge capacity through huge investments in education and research. Analysis has iptrfoctrd that a high GDP can be possible to acheive if Bnagladesh gives more importance to industry sectors, particularly, SMEs and entrepreneurs development. It is the expectation that 2016-2030 strategic planning for higher education will provide guideline in overcoming weaknesses in present education system and revitalization of universities and for linking higher education to development.

\section{Acknowledgment}

Books on education, statistical data and journals available from library of East West University, Dhaka, Bangladesh helped the authors in carrying out this research study. Authors of this paper would like to thank academics of Departments of Sociology and Economics for its various supports during the course of this work.

\section{References}

Kruss, G., McGrath, S., Petersen, S., Il-haam, \& Michael.(2015).Higher education and economic development: The importance of building technological capabilities International, Journal of Educational Development, vol. pp. 43, 22-31.

Brown, P., \& Lauder, H. (1996). Education, globalization and economic development, Journal of Education Policy, pp. 1-25.

UNESCO. (1991). The Role of Higher Education in Society: Quality and Pertinence. 2nd Collective Consultation on Higher Education, Paris, pp. 8- 11.

Shin, J. C. (2018). Higher Education Development in East Asian Countries Focusing on Cultural Tradition and Economic Systems, Neubauer et al. (eds.), International and Development Education series: Springer Nature.

Oliver, D. E. (2004). Higher Education Challenges in Developing Countries: The Case of Vietnam, International Journal of Educational Policy, Research \& Practice, vol. 5(2).

Kefela, G. T. (2010). Knowledge-Based Economy and Society Has Become a Vital Commodity to Countries International, Journal of Educational Research and Technology, Vol. 1(2), pp. 68-75.

Lopes, N.V., Bagarukayo, K., \& Jun, C. (2017). Knowledge Societies in China, Portugal, and Uganda, International Journal of Knowledge Society Research (IJKSR), vol. 8(4), pp. 2325.

McCowan, T., \& Schendel, R. (2015). The impact of higher education on development. McGrath, S., \& Gu, Q. (Eds.), Routledge Hand book of International Education and Development London: Routledge.

Hassan, M. M. S. (2016). Revamping Higher Education in Bangladesh. International Journal of Management and Applied Science (IJMAS), vol. 2(12), pp. 53-55.

Abdin. Md. J. (2016). For sustainable economic development of Bangladesh. The Independent. Nov.3. Available: https://www.researchgate.net/publication/309634087_ For_sustainable_economic_de velopment_of_Bangladesh/

Bangladesh Bureau of Statistics (BBS) (2016). Available: http://203.112.218.65:8008/ WebTestApplication/userfiles/Image/LatestReports/LFS_2016-17.pdf. 
Bangladesh Export Promotion Bureau (BEPB). (2017). Available: www.mof.gov.bd.

Bangladesh Economic Update (BEU). (2016), 7 (2).

Dickey, D.A., \& Fuller, W.A. (1981), Distribution of the estimators for the autoregressive time series with a unit root, Econometrica, vol. 49, pp. 1057-1072.

Johansen, S., \& Juselius, K. (1990), Maximum likelihood estimation and inference on cointegration with applications to the demand for money, Oxford Bull, Eco, Stat., vol. 52, pp. 169-210.

Gujarati, D. N. (2011), Basic Econometrics. $8^{\text {th }}$ ed. McGraw-Hill Publications, New York.

University Grants Commission of Bangladesh (UGC). 2016. Available: http://www.ugc.gov.bd.

Bloom, B.S., Media, B. \& Krathwohl, D. (1964). Taxonomy of Educational Objectives Handbook II: Affective Domain \& the Cognitive Domain. David McKay Company, New York.

Gibbs, G. (1992), Improving the Quality of Student Learning. Technical and Educational Services, Bristol. 